\title{
Assessing the Performance of Student Teachers in a Bachelor of Education Programmes at the University of Technology, Jamaica
}

\author{
Cynthia Onyefulu, Grace Hughes, Richard Samuels \\ Faculty of Education \& Liberal Studies, University of Technology, Jamaica \\ Email: conyefulu@gmail.com
}

How to cite this paper: Onyefulu, C., Hughes, G. and Samuels, R. (2019) Assessing the Performance of Student Teachers in a Bachelor of Education Programmes at the University of Technology, Jamaica. Open Access Library Journal, 6: e5449.

https://doi.org/10.4236/oalib.1105449

Received: May 7, 2019

Accepted: June 8, 2019

Published: June 11, 2019

Copyright $\odot 2019$ by author(s) and Open Access Library Inc.

This work is licensed under the Creative Commons Attribution International License (CC BY 4.0). http://creativecommons.org/licenses/by/4.0/

\section{Open Access}

\begin{abstract}
Teaching practice is an integral part of teacher education programmes around the world. All student teachers at the University of Technology (UTech), Jamaica are required to do a series of teaching practice courses, namely, one week of school observation, two weeks of team teaching, and 12 weeks of individual teaching. The main purpose of this study was to assess the performance of the student teachers in the Bachelor of Education Programmes at UTech, Jamaica. To answer the three research questions that guided the study, the ex-post facto research design was used. The scores from the theory lesson of 88 student teachers who participated in the 2011/12 teaching practice exercise were used. The results showed that some student teachers from the Business and Computing Studies programme got one to five visits during the teaching practice when compared to those in the Family and Consumer Studies, and the Industrial Technology groups who had three to five visits, respectively. The results showed that for Lesson Preparation, there was a statistically significant difference between the student teachers in the Business and Computing Studies and the Family and Consumer Studies. For Lesson Delivery, there was a statistically significant difference between the Business and Computing Studies and the Industrial Studies student teachers. There were no differences in the other two domains (Professionalism \& Classroom Management, \& Communication Skills). The results also showed that there was a weak positive relationship between the scores awarded by the programme and education specialists to the student teachers in the Business and Computing Studies only. There were no significant relationships for the scores awarded to the student teachers in the Industrial Technology, and Family and Consumer Studies programmes. Based on the findings, some recommendations were made on how to improve the teacher preparation programmes, including the teaching practice exercise.
\end{abstract}




\section{Subject Areas}

Education

\section{Keywords}

Student Teachers, Teaching Practicum, Teaching Practice Performance

\section{Introduction}

Teaching practice is an internship period where student teachers perform some roles such as teaching, managing the classroom and students' behaviours, assessing student learning, while reflecting on their practices (Ashraf [1], Andabai [2], Edem [3]). Teaching practice is seen as an integral part of a teacher education programme (Henry [4], Richard, Role, \& Makewa [5]), and considered as an essential component of teacher preparation, because it is seen as "the best way to acquire professional knowledge and competence as a teacher" (Cocard, \& Moser [6], p. 626). This crucial component of a teacher preparation programme is sometimes referred to as field experience (Edge [7]), or teaching practice (Fraser [8]). Others prefer to use the term "practice teaching, student teaching, teaching practice, field studies, infield experience, school-based experience or internship" (Richard, Role, \& Makewa [5], p. 43). In this study, it is referred to as teaching practice and/or practicum.

According to Ogonor and Badmus [9] and Richard, Role and Makewa [5], those who embank on this exercise are called student teachers. However, other authors use related terms. For instance, Edge [7] referred to them as "future teachers, prospective teachers, interns, rather than learners or students of teaching" (p. 37). Fraser [8] used the term "pre-service teachers" (p. 246), while Song [10] referred to them as teacher candidates. The term "student teacher" is used in this study.

For student teachers to acquire this knowledge, they are assigned to schools to teach, and this learning experience is supervised and assessed (Maphosa \& Ndamba [11]). During the practicum, student teachers are assigned to schools where they teach and participate in other school-related activities. These student teachers are also supervised and assessed during the practicum.

\subsection{Background of the Study}

The School of Technical and Vocational Education in the Faculty of Education and Liberal Studies (FELS) at the University of Technology, Jamaica is the first institution that prepares teachers to teach technical and vocational subjects in schools within and outside Jamaica. At the time, data for this study were collected. The Faculty offered two undergraduate teacher education programmes. These include a Bachelor of Education full-time (four-year) programme in Technical, Vocational Education and Training (B.Ed. TVET), and a part-time 
(B.Ed.) summer programme (Faculty of Education \& Liberal Studies [12]). Both programmes were offered in three areas of specialisation, namely Business and Computing Studies, Family and Consumer Studies, and Industrial Technology. The Faculty also offers a Postgraduate Diploma in Education programme in different subject areas during the summer semester. This study focused on the performance of student teachers in the full-time (four-year) B.Ed. in Technical, Vocational Education and Training programme in Business and Computing Studies, Family and Consumer Studies, and Industrial Technology.

All student teachers in the aforementioned programmes are required to do a series of teaching practice courses. These include one week of school observation, two weeks team teaching, and 12 weeks of individual teaching. Each is explained below.

1) One week of school observation (done in year 1, semester 1). This exercise is an initiation into the teaching profession for the student teachers. No university assessors are assigned to see the student teachers during the school observation exercise. However, student teachers are required to submit an observation booklet and would discuss their findings in a Foundations of Education course (Faculty of Education \& Liberal Studies [13]).

2) Two weeks of team teaching (done in year 3 , semester 1 ). This is an opportunity for the student teachers to teach before assuming full solo responsibility in their final year. The University assessors are assigned to see the students during the team teaching and the individual teaching exercises (Faculty of Education \& Liberal Studies [13]).

3) Twelve weeks of individual teaching (done in year 4, semester 2). During this exercise, the student teachers who are promoted to the final year of their programme, are posted to high schools in Jamaica to complete a three-month teaching practice exercise, between the period January to March each year. During this period, the student teachers are assigned to teach students mainly in grades nine to eleven. However, in exceptional cases when the high schools do not have enough spaces in the higher grades $(9-11)$, the student teachers may be assigned to the lower grades $(7-8)$. The experienced teachers whose classes are used for the practicum are expected to work closely with the student teachers and to perform mentoring roles. The cooperating teachers are not expected to formally assess the student teachers; however, they may provide feedback that will help the student teachers to improve their teaching skills and competencies.

4) The Key Players. In the Faculty of Education and Liberal Studies, there are four key players involved in the teaching practice exercise. These include the teaching practice coordinator, cooperating teachers, university (internal) assessors, and the external assessors. The teaching practice coordinator, whose responsibilities include establishing teaching practice policy, placing student teachers in schools, planning and organising the teaching practice exercise, and selecting the cooperating teachers, among others (Faculty of Education \& Liberal Studies [13]). The cooperating teachers, whose classes are used for the practicum, are expected to work closely with the student teachers by performing 
mentoring roles and providing feedback which would help the student teachers to improve their teaching skills and competencies. As indicated earlier, the cooperating teachers are not expected to formally assess the student teachers ( $\mathrm{Fa}$ culty of Education \& Liberal Studies [13]).

Lecturers from the three areas of specialisation mentioned earlier, as well as those from the education division, are referred to as supervisors or university (internal) assessors. These supervisors are responsible for observing and assessing as well as providing feedback to the student teachers who they have supervised during the three teaching practice exercises. There are also external assessors who are not employees of the university but are contracted to externally assess and submit grades for all the student teachers who participated in the 12 -week practicum. One of the external assessors is appointed as the chief external assessor. The chief external assessor has the responsibility of moderating both the internal and external grades and submitting a written report at the end of the exercise (Faculty of Education \& Liberal Studies [13]).

5) Teaching Practice Prerequisite. To ensure that the student teachers are ready for the practicum exercise, they must pass two courses in the curriculum, namely, special methods and instructional methods. In these courses, the student teachers are taught competencies on how to use different teaching strategies, which could impact learning. They must also pass all courses in their area of specialisation (Faculty of Education \& Liberal Studies [13]).

6) Teaching Practice Assessment. At the time of this study, the student teachers were assessed under four domains, namely, lesson preparation, lesson delivery, professionalism and classroom management, and communication skills by both the internal and external assessors in the three areas of specialisation. The response format for all four domains are as follows: Unable to Observe (U), Poor (1), Weak (2), Average (3), Good (4), and Excellent (5). See Table 1 for the number of items and weighting on the different domains.

\subsection{Statement of the Problem}

Each year, student teachers are assigned to different high schools within and around Kingston and St. Andrew for the practicum experience, and there has always been a concern about how the students are performing based on the scores they earned at the end of each teaching practice period. There is also an

Table 1. Distribution of items and weighting.

\begin{tabular}{ccc}
\hline Domain & Number of Items & Weighting (\%) \\
\hline Lesson Preparation & 13 & 20 \\
Lesson Delivery & 16 & 40 \\
Professionalism \& Classroom Management & 17 & 30 \\
Communication Skills & 6 & 10 \\
Total & 52 & 100 \\
\hline
\end{tabular}


on-going perception of the differences in the ways scores are assigned by the programme specialists and the education specialists (internal assessors). This perception has resulted in some lecturers expressing the view that programme specialists, that is, those internal assessors from the three areas of specialisation are more stringent than those from the education unit. However, no formal study has ever been done to ascertain if these concerns are real.

A review of the literature revealed several studies have been done on student teachers on teaching practice. However, there is little of study on the assessment of the performance of student teachers in Jamaica. This study is designed to address this gap in the existing literature.

\subsection{Purpose of the Study}

The main purpose of this study was to assess the performance of the student teachers in a Bachelor of Education Programmes at the University of Technology, Jamaica. The study was also aimed at determining if there was any association between the scores given by the education specialists and the programme specialists during the teaching practice exercise.

\subsection{Research Questions}

The following research questions were answered:

1) How frequently were student teachers assessed during the teaching practice exercise?

2) To what extent is there a difference in the performance of the student teachers from the three areas of specialisation in the four domains (lesson preparation, lesson delivery, professionalism and classroom management, \& communication skills) during the teaching practice exercise?

3) To what extent is there a relationship between the scores given by the programme and education specialists during the teaching practice exercise?

\subsection{Research Hypothesis}

The following null hypotheses were tested by using One Way Analysis of Variance (ANOVA) and Pearson's Product Moment $(r)$, respectively:

$\mathrm{Ho}_{1}$ : There is no difference in the performance of the student teachers from the three areas of specialisation in the four domains during the teaching practice exercise.

$\mathrm{Ho}_{2}$ : There is no relationship between the scores given by the programme and education specialists during the teaching practice exercise.

\section{Literature Review}

As indicated earlier, there are a lot of studies done across the world on teaching practice. These include but are not limited to studies done by Abongdia, Adu, and Foncha [14], Andabai [2], Babatunde [15], Ebrahim, Eyadat, and Alshammari [16], Field and Philpott [17], Hyndman [18], Kiggundu and Nayimuli [19], 
Liu and Qi [20], Mahmood and Iqbal [21], Magope and Otukile-Mongwaketse [22], Newton, Kadenyi, and Mukuna [23], Onyebukwa-Nwanoro [24], Onyefulu [25], and Rauduvaite, Lasauskiene, and Barkauskaite [26], to name a few.

Liu and Qi [20] assessed student teaching practice in two elementary teacher preparation programmes in China and the United States of America (USA) and found some similarities and differences between the two countries. For instance, more hours were allocated to student teaching in the US when compared to those in China. In terms of similarities, they also found that in both countries, student teachers used reflection journals in their professional portfolios, and in both countries, similar evaluation criteria were used for student teacher assessment. Other studies focused on the experiences and perceptions of student teachers. These include studies by Hyndman [18] that examined the differences in teaching perspectives of student teachers and graduates physical education teachers in Australia. The findings, among other things, found nurturing as the main teaching perceptive among the two groups. Rauduvaite, Lasauskiene, and Barkauskaite [26] who investigated the experiences of pre-service music teachers in a university in Northern Europe and found both positive (relationships with students, mentors, and other teachers, and self and professional development), and negative (lack of confidence, fear, and lack of professional readiness) experiences based on the teachers' reflections. Kiggundu and Nayimuli [19] also examined the experiences of student teachers during teaching practice in South Africa. In this qualitative study, the participants found their hands-on experiences in the classrooms to interesting due to constant supportive relation and guidance from most of their mentors, but difficult due to lack of self-confidence and intimated by some other teachers. In yet another qualitative study conducted by Magope and Otukile-Mongwaketse [22], they explored the teaching practice experiences of special education student teachers in a university in Botswana, and found that the participants also expressed both positive (e.g., valuable hands-on exercises) and negative (e.g., limited pedagogical knowledge \& skills) experiences with regards to inclusive classrooms. While others as such as Mahmood and Iqbal [21] in India; Newton, Kadenyi, and Mukuna [23] in Kenya; Ebrahim, Eyadat, and Alshammari [16] in Kuwait; Onyebukwa-Nwanoro [24] in Nigeria; and Abongdia, Adu, and Foncha [14] in South Africa, all examined challenges that face student teachers during teaching practice. Some of the challenged revealed, among other things, were lack of resources, professional and academic issues, large class sizes, the host schools, and attitudes of school staff and cooperating teachers.

Other authors examined the benefits of a teaching practice exercise. For instance, Andabai [2] evaluated the impact of teaching practice on trainee teachers in Nigeria, and the findings showed that trainee teachers benefited in the teaching practice exercise through participation in school activities, and developing their teaching skills. On the other hand, Field and Philpott [17] explored the impact of hosting students and concluded by stating that one of the benefits of teaching practice was that it provided "an opportunity for lifelong learning and 
continuous professional development for all involved in school" (p. 115).

There are also studies on the assessment of teaching practice. For instance, in South Africa, Fraser [8] explored issues related to competency-based assessment during teaching practice. According to Fraser [8], teaching practice calls for the assessment of competence in practice, and "the purpose of assessment is the collection of sufficient evidence of workplace performance to demonstrate that individuals can perform or behave to the specified standards in a specific role" ( $\mathrm{p}$. 248). Still on the issue of assessment, in Kenya, Richard, Role, and Makewa [5] investigated the differences in performance between male and female student teachers during the teaching practice exercise. Their findings showed that there were differences in the way the males viewed the feedback received, but there were also some similarities in the way the two groups viewed the collaborating teachers' attendance to their classes. Another study done in Malawi, Kaphesi [27] assessed the performance of final year undergraduate student teachers at their practicum. The findings showed that in some cases, the grades awarded by the assessors were lower than the written comments on the quality of the student teachers. The review of the literature also showed other assessment-related studies done on student teachers in practice. For instance, Hall and West [28] examined student teacher performance on emotional intelligence at a private university in the United States; in Africa, Nnenna and Olanrewaju [29] examined the relationship between teaching practice anxiety and performance in federal colleges of education in Southwestern Nigeria; similarly in Nigeria, Oluwatayo and Adebule [30] studied teaching practice performance by using Teaching Practice Assessment form designed by a Faculty of Education; and still in Nigeria, Ogonor and Badmus [9] examined reflective teaching practice among student teachers, while Onyefulu [25] investigated the characteristics of the teaching practice programme at the University of Technology, Jamaica. The literature has shown that there is a need to explore student teacher performance other than just to examine their perceptions, beliefs, and experiences. There is an important gap in the literature which this study was designed to fill.

\section{Research Methodology}

\subsection{Design and Sample}

This study was conducted using the ex-post facto research design. Data were collected using the teaching practice assessment form for theory lessons. The population of the study included all 88 student teachers who were assessed by 23 University assessors (that is, 10 assessors from the three areas of specialization \& 13 from the education unit) who participated in the 2011/12 teaching practice exercise. Therefore, no sampling was conducted. The teaching practice (theory forms) for all 88 student teachers who participated in the 12-week teaching practice in 20 high schools within and around Kingston and St. Andrew during that period were included in the studied. See Table 2 for the number of student teachers in each area of specialisation. 
Table 2. Distribution of student teacher by Area of specialisation.

\begin{tabular}{ccc}
\hline Area of Specialisation & $\begin{array}{c}\text { Number of Student } \\
\text { Teachers (n) }\end{array}$ & $\begin{array}{c}\text { Percent } \\
(\%)\end{array}$ \\
\hline Business \& Computing Studies & 29 & 33.0 \\
Family \& Consumer Studies & 28 & 31.8 \\
Industrial Technology & 31 & 35.2 \\
Total & 88 & 100.0 \\
\hline
\end{tabular}

\subsection{Data Collection}

Three different teaching practice scales were used for assessing student teachers at the University of Technology, Jamaica. These included the scales for assessing theory lesson, practical lesson, and test administration. The use of more than one instrument for assessing student teachers is supported by Fraser [8] who stated that "one assessment too or instrument will never be adequate enough to measure all the skills and competence of a student teacher" (p. 249).

Since this study was not aimed at assessing student teachers' overall competency, the scores used were obtained from the theory lesson assessment only. For the theory lesson, the student teachers were assessed using a scale with 52 items under the following sections: lesson preparation, lesson delivery, professionalism and classroom management, and communication skills. These items had the following response format: Unable to Observe without a value, No Attempt with a value of (0), Poor with a value of (1), Weak (2), Average (3), Good (4), and Excellent (5).

\subsection{Reliability Coefficient Analysis}

The Cronbach alpha reliability coefficient was computed with the scores from the teaching practice (theory) scale. This was done to ensure that the scores used in the study were reliable. The overall reliability coefficient was 0.919 . The sub-scale reliability coefficients ranged from 0.737 to .894 . Although several authors have quoted different acceptable reliability coefficients, Reynolds, Livingston, and Wilson (2006) [31] endorsed reliability estimates that are from 0.70 and above. See Table 3 for the reliability coefficients for the four sub-scales.

\subsection{Data Analysis}

The scores were coded and entered into SPSS version 21 and analysed using descriptive statistics (mean, standard deviation, frequency, \& percentage), and inferential statistics (ANOVA \& Pearson's Product Moment). It should be pointed out that although the numbers of student teachers in the three groups were unequal, the effects of violations of the ANOVA test assumptions were not considered as serious because of its robustness (Glass \& Hopkins [32]; Ravid [33]).

\section{Results}

During the 2011/12 teaching practice period, a total of 20 high schools in Eastern 
Table 3. Sub-scale reliability coefficients.

\begin{tabular}{ccc}
\hline Sub-Scale & Number of Items & Reliability Coefficient \\
\hline Lesson preparation & 13 & 0.845 \\
Lesson delivery & 16 & 0.894 \\
Professionalism \& classroom management & 17 & 0.761 \\
Communication skills & 6 & 0.737 \\
\hline
\end{tabular}

Jamaica schools were used. Thirteen of these schools are located in the parishes of Kingston and St. Andrew, while seven are outside these parishes. Three of these institutions where the student teachers did their practicum are referred to as technical high schools, while 17 were traditional high schools.

The student teachers from the Business and Computing Studies programme taught the following subjects: principles of accounting, principles of business, and information technology; those from the Family and Consumer Studies programme taught mostly home and family management, clothing and textiles, and food and nutrition; while those from the Industrial Technology programme taught electrical technology, industrial techniques, mechanical technology, technical drawing, machine shop, metalwork, woodwork, and building construction. It should be noted that some of these subjects do have practical components; however, this study only focused on the theory aspect of the lesson delivery.

\subsection{Frequency of Assessment during the Teaching Practice}

Research Question One: How frequently were student teachers assessed during the teaching practice exercise?

The number of times the student teachers were assessed during the three-month teaching practice was calculated from the assessors' log. See Table 4 for the frequency of the student teachers' teaching practice assessments. The log inspection revealed that a few student teachers in the Business and Computing Studies programme got only one visit during the teaching practice. The mode for this group was three assessments, indicating that 13 student-teachers were assessed three times. The mode for the Family and Consumer Studies group was four, which appeared 12 times, while the mode for the Industrial Technology group was three, which appeared 11 times.

\subsection{Student Teachers' Performance in the Four Domains}

Research Question Two: To what extent is there a difference in the performance of the student teachers from the three areas of specialisation in the four domains (lesson preparation, lesson delivery, professionalism and classroom management, \& communication skills) during the teaching practice exercise?

As shown in Table 5, the Business and Computing Studies student teachers performed better in all four domains with the mean values ranging from 76.3 to 87.7. The scores for the Industrial Technology, and the Family and Consumer Studies scores student teachers ranged from 72.9 to 81.0 , and 68.3 to 81.0, respectively. In terms of the spread of the scores, the standard deviation values 
Table 4. Number of assessments received by student teachers.

\begin{tabular}{ccc}
\hline Areas of Specialisation & $\begin{array}{c}\text { Number of Student } \\
\text { Teachers Assessed }\end{array}$ & Number of Assessments \\
\hline Business \& Computing Studies & 29 & $1-5$ \\
Family \& Consumer Studies & 28 & $3-5$ \\
Industrial Technology & 31 & $3-5$ \\
\hline
\end{tabular}

Table 5. Student teachers' performance in the four domains.

\begin{tabular}{cccccccc}
\hline \multirow{2}{*}{ Assessment Domain } & \multicolumn{2}{c}{$\begin{array}{c}\text { Family \& } \\
\text { Consumer Studies }\end{array}$} & \multicolumn{2}{c}{$\begin{array}{c}\text { Industrial } \\
\text { Technology }\end{array}$} & \multicolumn{2}{c}{$\begin{array}{c}\text { Business \& } \\
\text { Computing Studies }\end{array}$} \\
\cline { 2 - 7 } & Mean & SD & Mean & SD & Mean & SD \\
\hline Lesson Preparation & 68.3 & 4.73 & 72.9 & 6.19 & 76.3 & 5.29 \\
Lesson Delivery & 71.9 & 6.69 & 64.6 & 8.39 & 77.5 & 6.91 \\
Prof. \& Classroom Management* & 70.9 & 7.61 & 67.2 & 10.01 & 72.7 & 8.21 \\
Communication Skills & 81.0 & 2.51 & 81.0 & 2.77 & 87.7 & 9.73 \\
\hline
\end{tabular}

*Professionalism \& classroom management.

ranged from 5.29 to 9.73 when compared to the Industrial Technology and the Family and Consumer Studies scores, which ranged from 2.77 to 10.01, and 2.51 to 7.61, respectively. These figures showed that there was less spread in the scores obtained by the student teachers in the Business and Computing Studies programme.

Furthermore, the analysis of variance (ANOVA) was used to determine if there were differences in the student teachers' performance in the four domains. As shown in Table 6, there were significant differences in two domains, namely, Lesson Preparation $F(2,85)=6.488, \mathrm{p}=0.002$, and Lesson Delivery $F(2,85)=$ 9.856, $p=0.001$, respectively. Tukey's post-hoc multiple comparison test was used to determine which groups were different. The results showed that for Lesson Preparation, there was a statistically significant difference between the student teachers in the Business and Computing Studies and the Family and Consumer Studies. For Lesson Delivery, the Tukey test also showed there was a statistically significant difference between the Business and Computing Studies and the Industrial Studies student teachers.

There were no differences in the other two domains, namely, Professionalism and Classroom Management, and Communication Skills. The null hypothesis, there is no difference in the performance of the student teachers from the three areas of specialisation in the four domains during the teaching practice exercise, was therefore rejected.

\subsection{Relationship between Programme Specialists and Education Specialists}

Research Question Three: To what extent is there a relationship between the scores given by the programme and education specialists during the teaching 
Table 6. ANOVA Summary table comparing three groups on four domains on teaching practice.

\begin{tabular}{|c|c|c|c|c|c|}
\hline Source & $d f$ & SS & $M S$ & $F$ & $p$ \\
\hline \multicolumn{6}{|l|}{ Lesson Preparation } \\
\hline Between Groups & 2 & 387.930 & 193.965 & 6.488 & 0.002 \\
\hline Within Groups & 85 & 2541.149 & 29.896 & & \\
\hline Total & 87 & 2929.080 & & & \\
\hline \multicolumn{6}{|l|}{ Lesson Delivery } \\
\hline Between Groups & 2 & 1081.383 & 540.691 & 9.856 & 0.001 \\
\hline Within Groups & 86 & 4662.935 & 54.858 & & \\
\hline Total & 88 & 5744.318 & & & \\
\hline \multicolumn{6}{|c|}{ Profession \& Classroom Management } \\
\hline Between Groups & 2 & 350.484 & 175.242 & 2.291 & 0.107 \\
\hline Within Groups & 85 & 6501.880 & 76.493 & & \\
\hline Total & 87 & 6852.364 & & & \\
\hline \multicolumn{6}{|l|}{ Communication Skills } \\
\hline Between Groups & 2 & 82.245 & 41.122 & 1.147 & 0.323 \\
\hline Within Groups & 85 & 3048.653 & 35.867 & & \\
\hline Total & 87 & 3130.898 & & & \\
\hline
\end{tabular}

practice exercise?

To answer the above research question bivariate (Pearson's product moment) was computed. The overall $(n=88)$ obtained Pearson's coefficient was $(r=$ 0.329 ) significant at 0.001 level. This indicated that in general, there was a weak positive relationship between the scores given by the programme and education specialists during the teaching practice exercise. See Table 7 for the results of the relationship between the scores awarded by the programme and education specialists during the teaching practice exercise.

As shown in Table 7, there were no significant relationships for the scores awarded to the student teachers in the Industrial Technology, and Family and Consumer Studies programmes, although the mean values for the scores by the education specialists were slightly higher when compared to those by the programme specialists for those in the Family and Consumer Studies programme. The null hypothesis, there is no relationship between the scores given by the programme and education specialists during the teaching practice exercise, was therefore rejected.

\section{Discussion}

Regarding research question one, the findings showed that the number of times the student teachers were assessed during the three-month teaching practice ranged from one to five assessments. Although some student teachers had as many as five assessments in the three areas of specialisation, some in the Business and Computing Studies programme appeared to have had less assessment 
Table 7. Relationship between scores given by programme \& education specialists.

\begin{tabular}{cccccccc}
\hline \multirow{2}{*}{ Programme } & \multicolumn{2}{c}{$\begin{array}{c}\text { Programme } \\
\text { Specialists }\end{array}$} & \multicolumn{2}{c}{$\begin{array}{c}\text { Education } \\
\text { Specialists }\end{array}$} & $(r)$ & \multirow{2}{*}{$p$} \\
\cline { 2 - 5 } & Mean & SD & Mean & SD & & \\
\hline Family \& Con. Studies* & 75.0 & 10.2 & 77.6 & 8.7 & 0.351 & 0.067 \\
Industrial Technology & 68.8 & 11.0 & 76.0 & 8.1 & 0.107 & 0.565 \\
Bus. \& Comp. Studies & & 80.7 & 6.55 & 78.7 & 8.7 & 0.655 & 0.001 \\
\hline
\end{tabular}

${ }^{\star}$ Family \& consumer studies, ${ }^{\star * B}$ Business \& computer studies.

when compared to those in the Family and Consumer Studies, and Industrial Technology programmes. This finding is consistent with the study done by Mannathoko [34] in Botswana, which showed that some student teachers were not frequently assessed. This has serious implications for the quality of preparations of the student teachers.

Regarding research question two, the student teachers in the Business and Computing Studies programme performed better in all four domains, namely, lesson preparation, lesson delivery, professionalism and classroom management, and communication skills. This is followed by the student teachers in the Family and Consumer Studies, who obtained scores that were higher in lesson delivery, and professionalism and classroom management when compared to those in the Industrial Technology programme. These findings were consistent with the study done by Hyndman [18] in Australia, which found differences between disciplinary majors. Hyndman [18] stated that "comparing teaching perspectives will provide greater insight and reflection into the underlying values and components...” (p. 4).

It is important to note that the student teachers' scores in communication skills were higher (in the 80s) more than the scores for the pedagogical components across the three programmes. Prozesky [35] considered communication skills as an important aspect of effective teaching. A similar view was expressed by Khan, Khan, Zia-Ul-Islam and Khan [36] who stated that "effective communication skills are really important for a teacher in transmitting of education, classroom management and interaction with students in the class" (p. 18). It is, therefore, encouraging to know that these sets of student teachers performed well in communication skills.

Regarding research question three, the findings showed that there was a 2.0 point difference in the mean values between the scores awarded by the programme and education specialists for the Business and Computing Studies student teachers. Furthermore, the findings showed also that the scores awarded by the programme specialists for the Business and Computing Studies student teachers were higher than those awarded by the education specialists. Hence, there was a weak positive relationship between the scores awarded by the programme and education specialists for the student teachers in the Business and Computing Studies only. There were no significant relationships for the scores 
awarded to the student teachers in the Industrial Technology, and Family and Consumer Studies programmes, although the mean values for the scores by the education specialists were slightly higher when compared to those by the programme specialists for those in the Family and Consumer Studies programme. The null hypothesis was therefore rejected. Kaphesi [27] found a relationship between the assessment grades and the written comments by the assessors in Malawi. However, no other study was found to support these findings.

\section{Conclusion}

The main purpose of this study was to assess the performance of the student teachers in a Bachelor of Education Programmes at the University of Technology, Jamaica. The findings showed that the student teachers in the Business and Computing Studies programme performed well in the four domains (lesson preparation, lesson delivery, professionalism \& classroom management, \& communication skills). The results also showed that there was a weak positive relationship between the scores awarded by the programme and education specialists for the student teachers in the Business and Computing Studies only. There were no significant relationships for the scores awarded to the student teachers in the Industrial Technology, and Family and Consumer Studies programmes. These four areas of the theory lesson assessments are very important for the student teachers in training if they are to be good teachers. It is believed that the findings of this study will make a significant contribution to the way these student teachers are prepared for the teaching profession and how they are assessed by the internal university assessors.

\section{Recommendations}

The following recommendations are made based on the results:

1) It will be good to ensure that each student teacher gets more than one assessment. A student teacher who gets only one score shows that such a student will not benefit from the observation, assessments, and feedback from multiple assessors.

2) To minimize the difference in the grades awarded by the programme and education specialists, efforts should be made to ensure that the two sets of assessors are observing and providing feedback that are consistent with the knowledge and training provided to the student teachers prior to the practicum.

3) There is a need to investigate further why some of the student teachers in the Family and Consumer Studies, and Industrial Technology programmes had slightly lower scores under lesson preparation and professionalism and classroom management.

4) There is also a need to investigate why the student teachers in the Business Studies programme had higher scores under lesson preparation and professionalism and classroom management compared to those of the Family and Consumer Studies and Industrial Technology programmes. 


\section{Conflicts of Interest}

The authors declare no conflict of interest regarding the publication of this paper.

\section{References}

[1] Ashraf, M. (1999) Dictionary of Primary Education. A.P.H. Publishing Corporation, New Delhi.

[2] Andabai, P.W. (2013) The Impact of Teaching Practice on Trainee Teachers in the Nigerian Tertiary Institutions: The Niger Delta University Experience. Academic Journal of Interdisciplinary Studies, 2, 109-115. https://doi.org/10.5901/ajis.2013.v2n5p109

[3] Edem, D.A. (2003) Introduction to Educational Administration in Nigeria. Leotina Nigeria Ltd., Onitsha.

[4] Henry, M. (1989) Change in Teacher Education: Focus on Field Experiences. In: Braun, J., Ed., Reforming Teacher Education: Issues and New Directions, Longman, New York, 69-95.

[5] Richard, T., Role, E. and Makewa, L.N. (2014) Student Teacher Evaluation on Preparation, Supervision, Teaching Environment and Teaching Practice. Journal of Culture, Society and Development. An Open Access International Journal, 3, 43-51.

[6] Hascher, T., Cocard, Y. and Moser, P. (2007) Forget about Theory-Practice Is All? Students' Learning in Practicum. Teachers and Teaching. Theory and Practice, 10, 623-637. https://doi.org/10.1080/1354060042000304800

[7] Edge, C.U. (2015) On the Nature of Experience in Education of Prospective Teachers: A Philosophical Problem. International Journal of Learning, Teaching and Educational Research, 13, 29-41.

[8] Fraser, W.J. (1995) Teaching and Assessment of Competencies and Skills. Personnel Bulletin, 19, 2-17.

[9] Ogonor, B. and Badmus, M.M. (2006) Reflective Teaching Practice among Student-Teachers: The Case in a Tertiary Institution in Nigeria. Australian Journal of Teacher Education, 31, 1-11. https://doi.org/10.14221/ajte.2006v31n2.2

[10] Song, K.H. (2006) A Conceptual Model of Assessing Teaching Performance and Intellectual Development of Teacher Candidates: A Pilot Study in the USA. Teaching in Higher Education, 11, 175-190. https://doi.org/10.1080/13562510500527701

[11] Maphosa, R. and Ndamba, G.T. (2012) Supervision and Assessment of Student Teachers: A Journey of Discovery for Mentors in Bulawayo, Zimbabewe. Journal of Emerging Trends in Educational Research \& Policy Studies, 3, 76-82.

[12] Faculty of Education \& Liberal Studies (2013) Programme Document.

[13] Faculty of Education \& Liberal Studies (2013) Teaching Practice Guidelines.

[14] Abongdia, J.A., Adu, E.O. and Foncha, J.W. (2015) Pre-Service Teachers' Challenges during Teaching Practice in One University in the Eastern Cape, South Africa. International Journal of Educational Sciences, 11, 50-56. https://doi.org/10.1080/09751122.2015.11890374

[15] Babatunde, M.M. (2016) Teaching Practice Exercise and Classroom Performance of Ideal Teachers in Public Secondary Schools in Kwara State, Nigeria. Teacher Education and Curriculum Studies, 1, 49-53.

[16] Ebrahim, A., Eyadat, W. and Alshammari, F. (2017) Challenges in Teaching Practice at the College of Education Based on the Perceptions of Pre-Service Teachers: 
The Case for Kuwait University. The New Educational Review, 49, 250-260.

[17] Field, K. and Philpott, C. (2000) The Impact of Hosting Student Teachers on School Effectiveness and School Improvement. Journal of In-Service Education, 26, 115-137. https://doi.org/10.1080/13674580000200107

[18] Hyndman, B.P. (2014) Exploring the Differences in Teaching Perspectives between Australian Pre-Service and Graduate Physical Education Teachers. Journal of Physical Education and Sport, 14, 438-445.

[19] Kiggundu, E. and Nayimuli, S. (2009) Teaching Practice: A Make or Break Phase for Student Teachers. South African Journal of Education, 29, 345-358.

[20] Liu, P. and Qi, C. (2012) Student Teaching Practice in Two Elementary Teacher Preparation Programs. Australian Journal of Teacher Education, 37, 14-34. https://doi.org/10.14221/ajte.2012v37n1.7

[21] Mahmood, N. and Iqbal, Z. (2018) Challenges Faced by Prospective Teachers during Teaching Practice: Connecting Theory to Practice. Bulletin of Education Research, 40, 113-136.

[22] Magope, B. and Otukile-Mongwaketse, M. (2018) Teaching Practice Experiences in Inclusive Classrooms: The Voices of University of Botswana Special Education Student Teachers. International Journal of Whole Schooling, 14, 57-92.

[23] Newton, M.A., Kadenyi, M. and Mukuna, T. (2013) Challenges Facing Teacher Trainees on Teaching Practice: The Case of Maasai Mara University Students, Narok County, Kenya. African Journal of Education, Science and Technology, 2, 38-45.

[24] Onyebukwa-Nwanoro, C.J. (2017) Challenges of Student-Teachers during Teaching Practice in Nigeria. Journal of Educational Policy and Entrepreneurial Research, 4, 30-36.

[25] Onyefulu, C. (2002) The Characteristics of the Teaching Practice Program of the University of Technology, Jamaica: A Review. The Nigerian Academic Forum: A Multidisciplinary Journal, 2, 202-210.

[26] Rauduvaite, A., Lasauskiene, J. and Barkauskaite, M. (2015) Experience in Teaching Practice of Pre-Service Teachers: Analysis of Written reflections. Procedia-Social and Behavioural Sciences, 191, 1048-1053. https://doi.org/10.1016/j.sbspro.2015.04.526

[27] Kaphesi, E. (2013) Assessing Final Year Undergraduate Student Teachers on School Based Teaching Practicum at the Polytechnic of the University of Malawi: A Dual Assessment Process. African Journal of Teacher Education, 3, 1-17. https://doi.org/10.21083/ajote.v3i2.2732

[28] Hall, P.C. and West, J.H. (2011) Potential Predictors of Student Teaching Performance: Considering Emotional Intelligence. Issues in Educational Research, 21, 145-161.

[29] Nnenna, E.E. and Olanrewaju, M.K. (2015) Teaching Practice Anxiety Sources as Correlates of Teaching Performance among Student Teachers in Federal Colleges of Education in Southwestern Nigeria. European Scientific Journal, 11, 181-196.

[30] Oluwatayo, J.A. and Adebule, S.O. (2012) Assessment of Teaching Performance of Student-Teachers on Teaching Practice. International Education Studies, 5, 109-115. https://doi.org/10.5539/ies.v5n5p109

[31] Reynolds, C.R., Livingston, R.B. and Wilson, V. (2006) Measurement and Assessment in Education. Pearson, Boston.

[32] Glass, G.V. and Hopkins, K.D. (1996) Statistical Methods in Education and Psy- 
chology. 3rd Edition, Allyn \& Bacon, Boston.

[33] Ravid, R. (2005) Practical Statistics for Educators. 3rd Edition, University Press of America, Lanham.

[34] Mannathoko, M.C. (2013) Does Teaching Practice Effectively Prepare Student Teachers to Teach Creative and Performing Arts? The Case of Botswana. International Journal of Higher Education, 2, 115-121. https://doi.org/10.5430/ijhe.v2n2p115

[35] Prozesky, D.R. (2000) Communication and Effective Teaching. Community Eye Health, 13, 44-45. https://www.ncbi.nih.gov/pmc/articles/PMC1705977

[36] Khan, A., Khan, S., Zia-Ul-Islam, S. and Khan, M. (2017) Communication Skills of Teachers and Its Role in the Development of the Students' Academic Success. Journal of Education and Practice, 8, 18-21. 